\title{
ANALISIS PENGARUH RASIO KEUANGAN TERHADAP KINERJA BANK (Studi Kasus pada Perbankan yang Terdaftar di BEI Tahun 2011-2015)
}

\author{
Munir Nur Komarudin \\ munir.nur@uniku.ac.id
}

\section{Fakultas Ekonomi Universitas Kuningan}

\begin{abstract}
ABSTRAK
Penelitian ini bertujuan untuk mengetahui pengaruh Capital Adequacy Ratio (CAR) terhadap Return On Asset (ROA); pengaruh Non Nerforming Loan (NPL) terhadap ROA; pengaruh Net Interest Margin (NIM) terhadap ROA; pengaruh biaya operasional pendapatan operasional (BOPO) terhadap ROA; pengaruh Loan to Deposit Ratio (LDR) terhadap ROA; pengaruh CAR, NPL, NIM, LDR, BOPO secara simultan terhadap ROA bank yang terdaftar di BEI tahun 2011-2015.

Metode penelitian yang digunakan adalah metode deskriptif verifikatif. Pengolahan data dalam penelitian ini menggunakan perhitungan statistik regresi linier berganda. Selanjutnya, untuk mengetahui besarnya pengaruh CAR, NPL, NIM, BOPO dan LDR terhadap ROA menggunakan analisis koefisien determinasi, keberartian koefisien regresi linier berganda diketahui dengan menggunakan uji t. Kemudian untuk mengetahu pengaruh secara simultan menggunakan uji $\mathrm{f}$.

Hasil penelitian menunjukkan bahwa CAR tidak berpengaruh terhadap ROA. NPL tidak berpengaruh terhadap ROA. NIM berpengaruh positif dan tidak signifikan terhadap ROA. BOPO berpengaruh negatif dan signifikan terhadap ROA. LDR tidak berpengaruh terhadap ROA. Secara simultan CAR, NPL, NIM, BOPO dan LDR berpengaruh secara signifikan terhadap ROA bank yang terdaftar di BEI tahun 20112015.
\end{abstract}

Kata kunci : ROA, CAR, NPL, NIM, BOPO, LDR 


\begin{abstract}
This study aims to determine the effect of Capital Adequacy Ratio (CAR) on Return On Assets (ROA); The effect of Non Nerforming Loan (NPL) on ROA; The effect of Net Interest Margin (NIM) on ROA; The effect of operational cost of operating income (BOPO) on ROA; The effect of Loan to Deposit Ratio (LDR) on ROA; The effect of CAR, NPL, NIM, LDR, BOPO simultaneously against the ROA of banks listed on the BEI 2011-2015.

The research method used is descriptive method verifikatif. Data processing in this study using the calculation of multiple linear regression statistics. Furthermore, to know the effect of CAR, NPL, NIM, BOPO and LDR against ROA using coefficient of determination analysis, multi linier regression coefficient significance is known by using $t$ test. Then to know the effect simultaneously using test $f$.

The results showed that CAR had positive and insignificant effect on ROA. NPL has a negative and significant effect on ROA. NIM has a positive and insignificant effect on ROA. BOPO has a negative and significant effect on ROA. LDR has a positive and significant effect on ROA. Simultaneously CAR, NPL, NIM, BOPO and LDR have a significant effect on the ROA of banks listed in BEI 2011-2015.
\end{abstract}

Keywords: ROA, CAR, NPL, NIM, BOPO, LDR 


\section{PENDAHULUAN}

Menurut Dilley, Deborah K. (2010: 2), bank is an establishment for custody, loan, exchange, or issue of money, for the extension of credit, and for fascilitating the transmission of funds. Dari definisi tersebut, bisa diambil kesimpulan bahwa bank adalah lembaga

yang berhubungan dengan penitipan, pinjaman, pertukaran, dan hal-hal lain yang berhubungan dengan uang dalam rangka perluasan kredit dan proses transmisi atau perpindahan dana.

Melihat pengertian sebelumnya, bank merupakan suatu lembaga keuangan, yang memiliki usaha pokok berupa menghimpun dana pihak ketiga yang (sementara) tidak dipergunakan untuk kemudian menyalurkan kembali dana tersebut kepada masyarakat untuk jangka waktu tertentu. Bank berperan dalam mencari dan selanjutnya menghimpun dana dalam bentuk simpanan (deposit). Simpanan (deposit) ini sangat menentukan pertumbuhan suatu bank, hal ini disebabkan karena volume dana yang dapat dikembangkan oleh bank tersebut dalam bentuk pemberian kredit, pembelian efek-efek atau surat berharga dalam pasar uang.

Selama periode 1982-1988 sistem finansial Indonesia didominasi oleh perbankan, terutama bank-bank milik pemerintah. Sektor perbankan mengalami perkembangan pesat pada periode tersebut, dengan ditandai banyak berdirinya bank-bank swasta. Peran penting bank swasta nasional meningkat pada tahun 1988-1991 yang memfokuskan pada upaya penurunan hambatan dalam memasuki pasar dan penawaran yang menarik seperti bank komersial milik pemerintah. Hal ini ditandai dengan terbentuknya 40 bank swasta baru dan 15 bank patungan. Pada periode tersebut bank swasta mulai membuka cabang hingga ke pelosok. Pada April 1982 terdapat 1.640 cabang bank menjadi 2.842 cabang bank pada maret 1990, dan melonjak drastis pada tahun 1997-1998 menjadi 6.345 kantor cabang bank. (Mudrajad dan Suhardjono, 2002: 6).

Sampai pertengahan tahun 1990 sistem finansial Indonesia masih didominasi oleh sektor perbankan. Deregulasi perbankan telah mengurangi pangsa pasar bank-bank pemerintah dan naik tumbuhnya bank-bank swasta nasional dari sisi akumulasi kekayaan, penyaluran kredit dan penghimpunan dana pada sisi lain. Namun komposisi penguasaan pangsa pasar mengalami perubahan drastis ketika mulai memasuki tahun 1997 yang diakibatkan oleh krisis moneter. Akibat krisis moneter ini pemerintah mengeluarkan kebijakan yang melikuidasi 16 bank swasta nasional pada bulan November 1997. Bank-bank bermasalah antara lain Bank Andromeda, Bank Amrico, Bank Astria Raya, Bank Citra dan lain-lain. Dampak dari krisis moneter ini terus berlanjut dan pada tanggal 4 April 1998 pemerintah menghentikan kembali kegiatan operasi tujuh bank yang kinerjanya kurang baik dan tujuh bank lainnya dibawah pengawasan Badan Penyehatan Perbankan Nasional (BPPN). (Tarmizi dan Wilyanto, 2003: 121)

Di negara-negara berkembang umumnya, sektor keuangan masih didominasi oleh sektor perbankan. Sampai tahun 2013, di Indonesia terdapat 5 Bank Persero, 42 Bank Umum Swasta Nasional (BUSN) Devisa, 32 Bank Umum Swasta Nasional (BUSN) Non Devisa, 28 Bank Campuran, dan 11 Bank Asing 
(www.bi.go.id, diakses pada tanggal 23 Desember 2013). Begitu banyaknya jumlah bank tentu menambah risiko yang dihadapi, apalagi jika ada bank besar yang mempunyai risiko sistemik akan dapat mengancam perekonomian Indonesia. Maka dari itu, bank harus menjaga kepercayaan masyarakat berkaitan fungsinya sebagai agent of trust.

Krisis moneter yang terjadi di Indonesia secara umum disebabkan oleh lemahnya kualitas sistem perbankan (menurut Pohan dikutip dari Rusdiana, 2002: 13). Lemahnya kualitas sistem perbankan tersebut dapat dilihat dari lemahnya kondisi internal sektor perbankan dan lemahnya manajemen bank. Kondisi perbankan tersebut mendorong pihak-pihak yang terlibat didalamnya untuk melakukan penilaian atas kesehatan bank (Mahardian, 2008: 17). Adapun manfaat dari mengetahui kinerja bank salah satunya adalah untuk meyakinkan investor supaya berinvestasi pada bank.

Tujuan fundamental

bisnis perbankan adalah memperoleh keuntungan optimal dengan jalan memberikan layanan jasa keuangan kepada masyarakat. Bagi pemilik saham menanamkan modalnya pada bank bertujuan untuk memperoleh penghasilan berupa deviden atau mendapatkan keuntungan dari peningkatan harga saham yang dimiliki (Capital gain) (Mudrajad dan Suhardjono, 2002: 131).

Penting bagi bank untuk senantiasa menjaga kinerja dengan baik, terutama menjaga tingkat profitabilitas yang tinggi (Mudrajad dan Suhardjono, 2002: 124). Dalam melakukan kegiatan operasionalnya, bank memiliki tujuan utama yaitu mencapai tingkat profitabilitas yang optimal.
Profitabilitas merupakan kemampuan bank untuk menghasilkan atau memperoleh laba secara efektif dan efisien. Oleh karena itu, profitabilitas merupakan faktor yang sangat penting dalam menilai tingkat kesehatan bank, karena profitabilitas menunjukkan kemampuan bank tersebut dalam memperoleh laba yang diharapkan. Rasio profitabilitas memberikan gambaran tentang tingkat efektifitas pengelolaan aset bank.

Dalam mengukur profitabilitas terdapat beberapa rasio yang dapat digunakan, di antaranya adalah Return on Asset (ROA), Return on Equity (ROE), Net Interest Margin (NIM), Net non Interest Margin, Net Operating Margin, dan Earning per Share (EPS) (Peter S. Rose dan Sylvia C. Hudgins, 2008:167). Namun dalam peraturan Bank Indonesia (PBI) No. 6/10/PBI/2004 tentang Sistem Penilaian Tingkat Kesehatan bank umum, komponen yang digunakan untuk mengukur faktor profitabilitas ialah ROA, ROE, NIM, dan tingkat efisiensi bank. Namun dalam penentuan tingkat kesehatan bank, Bank Indonesia lebih menekankan pentingnya penilaian berdasarkan ROA yang merupakan rasio jumlah laba bersih dibandingkan dengan jumlah aktiva.

Tabel 1.1

Profitabilitas (ROA) Beberapa Bank Umum Yang Terdaftar di BEI

\begin{tabular}{|l|l|l|l|}
\hline \multirow{2}{*}{ Nama Bank } & \multicolumn{3}{|c|}{ Nilai Profitabilitas(ROA) } \\
\cline { 2 - 4 } & $\begin{array}{l}\text { Tahun } \\
2013\end{array}$ & $\begin{array}{l}\text { Tahun } \\
2014\end{array}$ & $\begin{array}{l}\text { Tahun } \\
2015\end{array}$ \\
\hline Bank Dinar Tbk & 1.46 & 0.32 & 1 \\
\hline $\begin{array}{l}\text { Bank CIMB } \\
\text { Niaga Tbk }\end{array}$ & 2.75 & 1.6 & 0.21 \\
\hline $\begin{array}{l}\text { Bank Ekonomi } \\
\text { Raharja Tbk }\end{array}$ & 1.19 & 0.3 & 0.11 \\
\hline $\begin{array}{l}\text { Bank Mayora } \\
\text { Tbk }\end{array}$ & 0.36 & 0.64 & 1.24 \\
\hline
\end{tabular}




\begin{tabular}{|l|l|l|l|}
\hline $\begin{array}{l}\text { Bank Mandiri } \\
\text { Tbk }\end{array}$ & 3.66 & 3.57 & 3.15 \\
\hline Rata - rata ROA & 1.88 & 1.28 & 1.14 \\
\hline
\end{tabular}

Sejalan dengan dengan teori yang diungkapkan oleh Kasmir (2004: 21) "Nilai ROA yang baik atau dapat dikatakan sehat adalah lebih besar dari $1.5 \%$ ", serta menurut Peraturan Bank Indonesia No.13/ 1/ PBI/ 2011 tentang penilaian tingkat kesehatan bank umum, bank dapat dikatakan sehat jika memiliki profitabilitas (ROA) minimal $1.5 \%$ dan dikatakan tidak sehat apabila memiliki profitabilitas (ROA) dibawah $1.5 \%$. Mengacu pada Tabel 1.1 ratarata profitabilitas (ROA) tiap tahunnya cenderung menurun serta nilai profitabilitas (ROA) dua tahun terakhir dibawah $1.5 \%$ menunjukan bahwa kondisi bank-bank tersebut dapat dikatakan tidak sehat. Sesuai dalam lampiran Surat Edaran (SE) Bank Indonesia No. 6/23/DPNP Bank dapat dikatakan sehat jika minimal memiliki profitabilitas (ROA) sebesar $1.5 \%$, ROA dihitung dari perbandingan antara laba sebelum pajak dengan rata-rata total aset. Melihat rata-rata profitabilitas (ROA) yang masih dibawah $1.5 \%$, menunjukkan bahwa kinerja bank-bank yang ada di Indonesia belum optimal atau dapat dikatakan tidak sehat, hal ini sejalan jika kondisi bank memiliki profitabilitas (ROA) dibawah $1.5 \%$ (tidak sehat). Jika tidak segera ditangani dengan menerapkan prinsip kehatihatian dan manajemen risiko dalam melaksanakan kegiatan usahanya, maka bank-bank tersebut dinilai tidak mampu menghadapi pengaruh negatif yang signifikan dari perubahan kondisi bisnis dan faktor eksternal lainnya yang pada akhirnya bank tidak dapat memenuhi kegiatan usahanya.

Melihat ketidak konsistenan pada penelitian-penelitian terdahulu maka penulis tertarik untuk melakukan penelitian lanjutan mengenai aspek Capital Adequacy Ratio (CAR), Non Performing Loan (NPL), Net Interest Margin (NIM), Biaya Operasi dibanding dengan Pendapatan Operasi (BOPO), dan Loan to deposit Ratio (LDR) terhadap kinerja bank yang diproksikan dengan menggunakan Return On Asset (ROA). Selain itu, perbedaan penulis dengan penelitian sebelumnya yaitu pada periode pengamatan. Kemudian sampel yang digunakan adalah perusahan perbankan yang terdaftar di Bursa Efek Indonesia (BEI) dari tahun 2011-2015. Oleh karena itu penulis mengambil judul penelitian "Analisis Pengaruh Rasio Keuangan Terhadap Kinerja Bank (Studi Kasus pada Perbankan yang Terdaftar di BEI Tahun 2011-2015)".

\section{PENGERTIAN BANK}

Undang-Undang Nomor

7 tahun 1992 tentang "Perbankan" sebagaimana telah diubah dengan Undang-Undang No.10 Tahun 1998 menyebutkan bahwa bank adalah badan usaha yang menghimpun dana dari masyarakat dalam bentuk simpanan dan menyalurkannya kepada masyarakat dalam bentuk kredit dan atau bentukbentuk lainnya dalam rangka meningkatkan taraf hidup rakyat banyak. Dalam Undang-Undang tersebut juga dijelaskan bahwa bank dibagi menjadi dua jenis, yaitu bank umum dan bank perkreditan rakyat (BPR).

\section{KINERJA PERBANKAN}

Asumsi umum yang mendasari banyak penelitian dan diskusi kinerja keuangan adalah bahwa meningkatkan kinerja keuangan akan menyebabkan peningkatan fungsi dan kegiatan 
organisasi (Alkhatib, 2012:105). Kinerja merupakan hasil dari sasaran yang ingin dicapai perusahaan yang diukur dalam periode tertentu. Perkasa (2007:127) mengatakan bahwa pengukuran-pengukuran yang digunakan untuk menilai kinerja tergantung pada bagaimana unit organisasi akan dinilai dan bagaimana sasaran akan dicapai

\section{CAR}

Untuk mengukur permodalan digunakan rasio Capital Adequacy Ratio (CAR). CAR adalah rasio kinerja bank untuk mengukur kecukupan modal yang dimiliki bank untuk menunjang aset yang mengandung atau menghasilkan risiko, misalkan kredit yang diberikan bank. Sementara menurut Peraturan Bank Indonesia, CAR (Capital Adequancy Ratio) adalah rasio yang memperlihatkan seberapa besar jumlah seluruh aktiva bank yang mengandung risiko (kredit, penyertaan, surat berharga, tagihan pada bank lain) ikut dibiayai dari modal sendiri disamping memperoleh dana-dana dari sumber-sumber diluar bank. Angka rasio CAR yang ditetapkan oleh PBI No.15/12/PBI/2013 tentang Kewajiban Penyediaan Modal Minimum Bank Umum, nilai minimum yang wajib dipenuhi bank sebesar 8 persen.

\section{NPL}

NPL merupakan besarnya jumlah kredit bermasalah pada suatu bank dibanding dengan total keseluruhan kreditnya. Kredit dalam hal ini merupakan kredit yang diberikan oleh bank kepada pihak ketiga yaitu nasabah pribadi atau badan, tidak termasuk kredit kepada bank lain. Kredit yang termasuk golongan kredit bermasalah adalah kredit kurang lancar, diragukan, dan macet.

\section{NIM}

Rasio NIM digunakan untuk mengukur manajemen bank dalam mengelola aset produktif untuk memperoleh pendapatan bunga bersih. Pendapatan bunga bersih diperoleh dari pendapatan bunga dikurangi beban bunga. Dalam Surat Edaran Bank Indonesia No.15/7/DPNP tanggal 8 Maret 2013 dijelaskan bahwa semakin besar rasio NIM maka semakin baik bagi bank. Semakin besar nilai rasio NIM mencerminkan semakin efektif pengelolaan aset produktif bank dalam bentuk kredit.

\section{BOPO}

Bank yang sehat adalah bank yang rentabilitasnya terus meningkat. Rasio yang digunakan dalam aspek rentabilitas adalah BOPO (Biaya Operasional dibanding Pendapatan Operasional). Biaya operasi merupakan biaya yang dikeluarkan oleh bank dalam rangka mengoperasikan usaha utama seperti biaya bunga, biaya pemasaran, biaya tenaga kerja dan biaya operasi lainnya. Pendapatan operasi merupakan pendapatan utama bank yang diperoleh dari penempatan dana dalam bentuk kredit dan pendapatan operasi lainnya. Dalam Surat Edaran Bank Indonesia No.15/7/DPNP tanggal 8 Maret 2013 dijelaskan bahwa rasio BOPO yang harus dijaga bank umum tidak lebih dari $85 \%$. Semakin kecil rasio BOPO mencerminkan bahwa semakin efisien bank dalam mengoperasikan usahanya.

\section{LDR}

Rasio LDR menyatakan seberapa jauh kemampuan bank dalam membayar kembali penarikan dana yang 
dilakukan nasabah dengan mengandalkan kredit yang diberikan sebagai sumber likuiditasnya. Rasio ini juga merupakan indikator kerawanan dan kemampuan dari suatu bank. Sesuai dengan ketentuan Bank Indonesia dalam SE BI No.15/41/DKMP tanggal 1 Oktober 2013, batas bawah LDR yang masih bisa ditoleransi sebesar $78 \%$ dan batas atas sebesar $100 \%$ Semakin tinggi rasio tersebut mencerminkan bahwa semakin rendahnya kemampuan likuiditas bank yang bersangkutan. Hal ini disebabkan karena jumlah dana yang diperlukan untuk membiayai kredit menjadi semakin besar.

\section{ROA}

Rasio Return On Assets (ROA)
dapat dijadikan sebagai ukuran kesehatan keuangan. Dalam penelitian ini ROA digunakan sebagai indikator kinerja bank. ROA merupakan perbandingan laba sebelum pajak terhadap total aset. Rasio ini menunjukkan seberapa besar kemampuan aset yang ada untuk menghasilkan tingkat pengembalian atau pendapatan. Menurut Belkaui dan Riahi (2011:152), ROA digunakan untuk mengukur kinerja keuangan perusahaan-perusahaan multinasional khususnya jika dilihat dari sudut pandang profitabilitas dan kesempatan investasi.

\section{HIPOTESIS PENEITIAN}

Hipotesis 1 : Capital Adequacy Ratio (CAR) berpengaruh positif terhadap

Return On Asset.

Hipotesis 2 : Non Performing Loan berpengaruh negatif terhadap Return On Asset (ROA).

Hipotesis 3: Net Interest Margin (NIM) berpengaruh positif terhadap Return On Asset (ROA).
Hipotesis 4 : Biaya Operasional dibandingkan dengan Pendapatan Operasional (BOPO) berpengaruh negatif terhadap Return On Asset (ROA).

Hipotesis 5 : Loan to Deposit Ratio (LDR) berpengaruh positif terhadap Return On Asset (ROA).

Hipotesis 6 : CAR, NPL, NIM, BOPO dan LDR berpengaruh secara simultan terhadap ROA.

\section{DESAIN PENELITIAN}

Metode yang akan digunakan dalam penelitian ini adalah deskriptif dan verifikatif. Metode deskriptif menurut Wibisono (2008:21) bertujuan untuk "Menggambarkan karakteristik sebuah populasi atau suatu fenomena yang sedang terjadi".

Umi Narimawati (2007:61) metode Verifikatif ialah "Pengujian hipotesis penelitian melalui alat analisis statistik". Penelitian ini bermaksud untuk menguji hipotesis dengan menggunakan perhitungan statistik.

Tabel 3.1

Operasionalisasi Variabel

\begin{tabular}{|c|c|c|c|}
\hline Variabel & Dimensi & Indikator & $\begin{array}{c}\text { Skala } \\
\text { Pengukuran }\end{array}$ \\
\hline $\begin{array}{l}\text { Permodalan } \\
\left(X_{1}\right)\end{array}$ & $\begin{array}{l}\text { Peraturan } \\
\text { Bank } \\
\text { Indonesia } \\
\text { No.15/2/PBI/2 } \\
013 \text {, }\end{array}$ & $\mathrm{CAR}=\frac{\text { Modal Bank }}{\text { Total ATMR }}$ & Skala Rasio \\
\hline $\begin{array}{l}\text { Kualitas } \\
\text { Aset }\left(X_{2}\right)\end{array}$ & $\begin{array}{l}\text { Peraturan } \\
\text { Bank } \\
\text { Indonesia } \\
\text { No.15/2/PBI/2 } \\
013,\end{array}$ & $\begin{array}{l}\text { NPL } \\
=\frac{\text { Total Kredit Bermasalah }}{\text { Total Kredit }}\end{array}$ & Skala Rasio \\
\hline $\begin{array}{l}\text { Manajemen } \\
\left(X_{3}\right)\end{array}$ & $\begin{array}{l}\text { Peraturan } \\
\text { Bank } \\
\text { Indonesia } \\
\text { No.15/2/PBI/2 } \\
013 \text {, }\end{array}$ & $\begin{array}{c}\text { NIM }= \\
\text { Pendapatan Bunga Bersih } \\
\text { Rata-rata aset Produktif }\end{array}$ & Skala Rasio \\
\hline $\begin{array}{l}\text { Rentabilitas } \\
\left(X_{4}\right)\end{array}$ & $\begin{array}{l}\text { Peraturan } \\
\text { Bank } \\
\text { Indonesia } \\
\text { No.15/2/PBI/2 } \\
013 \text {, }\end{array}$ & $\begin{array}{l}\text { BOPO } \\
=\frac{\text { Biaya Operasional }}{\text { Pendapatan Operasional }}\end{array}$ & Skala Rasio \\
\hline $\begin{array}{l}\text { Liquiditas } \\
\left(X_{5}\right)\end{array}$ & $\begin{array}{l}\text { Peraturan } \\
\text { Bank } \\
\text { Indonesia } \\
\text { No.15/2/PBI/2 }\end{array}$ & LDR $=\frac{\text { Total Kredit }}{\text { Total DPK }}$ & Skala Rasio \\
\hline
\end{tabular}




\begin{tabular}{|l|l|l|}
\hline & 013, & \\
\hline Kinerja & Peraturan \\
Bank & Indonesia \\
& $\begin{array}{l}\text { No.15/2/PBI/2 } \\
013,\end{array}$
\end{tabular}
$\begin{aligned} & \text { Sumber: dikembangkan untuk penelitian ini, } 2017 \\
& \text { ToA }=\frac{\text { Labasebelum Pajak }}{\text { Total Aset }}\end{aligned}$
JENIS DAN
PENGUMPULAN DATA
Penulis menggunakan data
sekunder karena mengambil data dari website Bank Indonesia (BI) yaitu www.bi.co.id, website Bursa Efek Indonesia www.idx.co.id, serta website ojk www.ojk.co.id

Creswell

menjelaskan "Teknik pengumpulan data merupakan usaha membatasi penelitian, mengumpulkan informasi melalui observasi dan wawancara, baik yang terstruktur maupun tidak, dokumentasi, materi-materi visual, serta usaha merancang protokol untuk merekam/ mencatat informasi”.Teknik pengumpulan data yang dilakukan dalam penelitian ini adalah berupa studi dokumentasi. Studi dokumentasi ini dilakukan dengan cara mengumpulkan data-data berupa laporan keuangan yang berhubungan dengan penelitian.

\section{POPULASI}

Menurut Arikunto, (2006:130) "Populasi merupakan keseluruhan subjek penelitian", sedangkan menurut Sugiyono (2008:80) "Populasi adalah wilayah generalisasi yang terdiri atas objek atau subjek yang mempunyai kuantitas atau karakteristik tertentu yang diterapkan oleh peneliti untuk dipelajari dan kemudian ditarik kesimpulan". Dalam setiap penelitian, populasi yang dipilih erat kaitannya dengan masalah yang akan diteliti. Populasi yang akan diambil dalam penelitian ini adalah bank-bank yang terdaftar di Bursa Efek Indonesia (BEI)

pada periode pelaporan BEI tahun 2011

sampai dengan tahun 2015.

Sampel menurut Arikunto, (2006:131) adalah "Sebagian atau wakil populasi yang diteliti", sedangkan menurut Sugiyono (2008:81) "Sampel adalah bagian dari jumlah dan karakteristik yang dimiliki oleh populasi tersebut". Adapun teknik sampling yang digunakan adalah sampel jenuh. Sampel jenuh (sensus) menurut Sugiyono (2008:85) adalah "Teknik penentuan sampel apabila semua anggota populasi digunakan sebagai sampel". Namun dalam pengambilan sampel jenuh hanya dilakukan pada jumlah polpulasi yang terhingga dan relatif kecil, hal ini sejalan dengan teori Arikunto (2006) penggunaan sampel jenuh hanya bisa dilakukan apabila jumlah populasi terhingga dan relative kecil.

Berdasarkan uraian diatas maka yang menjadi sampel dalam penelitian ini adalah 43 bank yang terdaftar di BEI pada periode pelaporan tahun 2011 sampai dengan tahun 2015, dan diambil laporan keuangannya tahun selama 5 tahun periode tersebut.

\section{UJI ASUMSI KLASIK}

Sebelum melakukan pengujian hipotesis dengan analisis regresi berganda, harus dilakukan uji klasik terlebih dahulu. Uji asumsi klasik dalam penelitian ini digunakan untuk mengetahui hubungan antar variabel yang ada dalam model regresi. Pengujian yang digunakan dalam penelitian ini adalah uji normalitas, uji multikolinearitas, uji heteroskedastisitas dan uji autokorelasi. 


\section{ANALISIS REGRESI BERGANDA}

Metode analisis yang digunakan dalam penelitian ini adalah regresi berganda dengan menggunakan aplikasi SPSS. Analisis regresi berganda digunakan untuk menguji data mengenai ketergantungan variabel dependen dengan variabel independen dengan tujuan untuk mengestimasi ratarata populasi atau nilai rata-rata variabel dependen berdasarkan nilai variabel independen yang diketahui. Persamaan regresi linier berganda dalam penelitian ini adalah sebagai berikut:

$Y=a+b_{1} X_{1}+b_{2} X_{2}+b_{3} X_{3}+b_{4} X_{4}+$ $b_{5} X_{5}+\mathrm{e}$

\section{PENGUJIAN HIPOTESIS}

Menurut Ghozali (2011:103), ketepatan fungsi regresi sampel dalam menentukan nilai aktual dapat diukur dengan Goodness of fit-nya. Secara statistik, setidaknya ini dapat diukur dari nilai koefisien determinasi, nilai statistik F, dan nilai statistik t. Perhitungan statistik disebut signifikan secara statistik apabila uji nilai statistiknya berada dalam daerah kritis (daerah dimana Ho ditolak). Sebaliknya disebut tidak signifikan bila uji nilai statistiknya berada dalam daerah dimana Ho diterima.

\section{KOEFISIEN DETERMINASI}

Koefisien determinasi $\left(R^{2}\right)$ digunakan untuk mengukur kemampuan model dalam menjelaskan variasi variabel dependen. Nilai koefisien determinasi adalah antara nol dan satu. Nilai koefisien determinasi yang kecil mencerminkan kemampuan variabelvariabel independen dalam menjelaskan variasi variabel dependen amat terbatas (Ghozali, 2011:103).

\section{UJI SIGNIFIKAN PARAMETER INDIVIDUAL (UJI t)}

Menurut Ghozali (2011:112) uji statistik t pada dasarnya menunjukkan seberapa jauh pengaruh satu variabel independen secara individual dalam menerangkan variasi variabel dependen.

\section{UJI SIGNIFIKAN SIMULTAN (UJI} F)

Ghozali (2011:114) menyatakan bahwa uji statistik $F$ pada dasarnya menunjukkan apakah semua variabel yang dimasukkan dalam model mempunyai pengaruh secara bersamasama terhadap variabel dependen.

Uji $\mathrm{F}$ digunakan untuk melihat apakah variabel independen berpengaruh secara simultan terhadap variabel dependen. Pengujian ini dilakukan dengan membandingkan nilai $\mathrm{F}$ hitung dengan nilai $\mathrm{F}$ kritis. Apabila nilai $\mathrm{F}$ hitung lebih besar dari $\mathrm{F}$ kritis dengan alpha 0.05 maka $\mathrm{H} 0$ ditolak dan Ha diterima, begitupula sebaliknya.

Pengujian ini juga dapat dilakukan dengan melihat probabilitas $\mathrm{F}$ hitung. Apabila probabilitas $\mathrm{F}<0.05$ maka $\mathrm{H} 0$ ditolak dan Ha diterima yang artinya variabel independen secara simultan berpengaruh terhadap variabel dependen. Sebaliknya apabila probabilitas $\mathrm{F}$ hitung lebih tinggi dari alpha 0.05 (prob $\mathrm{F}>0.05$ ) maka $\mathrm{H} 0$ diterima dan Ha ditolak.

\section{HASIL DAN PEMBAHASAN}

Tabel 3

Statistik Deskriptif Data Panel

Descriptive Statistics

\begin{tabular}{|l|c|c|c|r|c|}
\hline & $\mathrm{N}$ & $\begin{array}{c}\text { Minim } \\
\text { um }\end{array}$ & $\begin{array}{c}\text { Maxi } \\
\text { mum }\end{array}$ & $\begin{array}{c}\text { Mean } \\
\text { Deviation }\end{array}$ \\
\hline CAR & 215 & 8.02 & 68.60 & $\begin{array}{r}17.90 \\
27\end{array}$ & 6.21475 \\
NPL & 215 & .00 & 4.91 & $\begin{array}{r}1.631 \\
8\end{array}$ & 1.18417 \\
NIM & 215 & 1.64 & 16.64 & 5.365 & 2.09193 \\
BOPO & 215 & 47.60 & 173.8 & 85.81 & 16.22026 \\
& & & 0 & 34 &
\end{tabular}


\begin{tabular}{|l|r|r|r|r|r|} 
LDR & 215 & 36.42 & 112.5 & 83.40 & 12.67965 \\
ROA & 215 & -7.58 & 5.42 & 1.595 & 1.76194 \\
$\begin{array}{l}\text { Valid N } \\
\text { (listwise) }\end{array}$ & 215 & & & 6 & \\
\hline
\end{tabular}

Sumber : Data Diolah

Berdasarkan Tabel di atas, untuk variabel ROA nilai terendah sebesar 7.58 yakni Bank JTrust Indonesia, Tbk. Sedangkan nilai tertinggi sebesar 5.42 yakni Bank Mestika Dharma, Tbk. Untuk variabel CAR, nilai terendah sebesar 8.02 yakni Bank BPD Banten, Tbk, sedangkan nilai tertinggi sebesar 87.49 yakni Bank Natinalnobu. Nilai mean variabel CAR sebesar 17.9027. Untuk variabel kualitas aset diproksikan dengan rasio keuangan NPL (Non Performing Loan), berdasarkan Tabel diatas nilai terendah variabel NPL sebesar 0.00 yakni Bank Danamon, Tbk, sedangkan nilai tertinggi sebesar 4.91 yakni Bank BPD Banten, Tbk. Untuk variabel kualitas manajemen diukur diproksikan dengan rasio keuangan NIM. Berdasarkan Tabel diatas nilai terendahnya adalah 1.64 yakni Bank JTrust Indonesia, Tbk, edangkan nilai tertingginya yakni 16.64 dimiliki oleh Bank BPD Banten, Tbk. Rasio keuangan yang mengukur efisiensi operasi adalah BOPO. Nilai terendah variabel BOPO sebesar 47.6 yakni Bank Panin Syariah dan nilai tertinggi sebesar 173.8 yakni Bank JTrust Indonesia, Tbk. Nilai mean variabel BOPO dalam Tabel diats sebesar 85.8134. Untuk variabel LDR, nilai terendah sebesar 36.42 yakni Bank JTRust Idonesia, Tbk dan nilai tertinggi sebesar 112.54 yaitu Bank QNB Indonesia.

\section{Tabel 4}

Hasil Uji Distribusi Normal One-Sample Kolmogorov-Smirnov Test

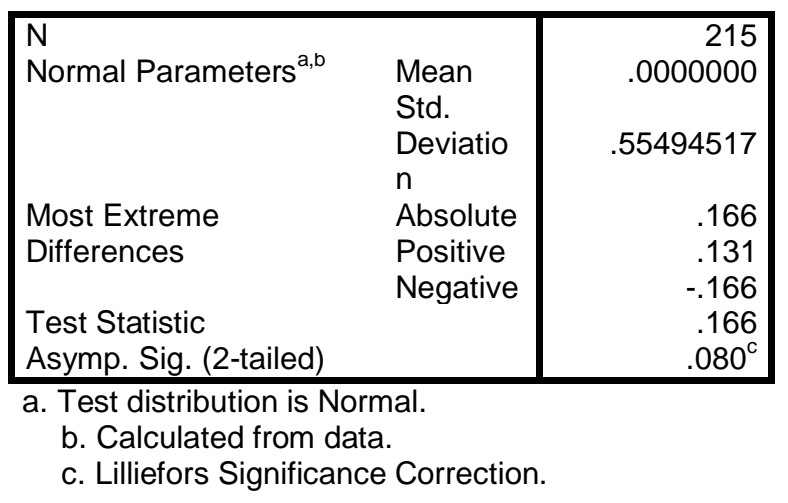

Dari tabel diatas dapat diketahui nilai signifikansinya adalah 0.080 lebih besar dari 0.05 , artinya data tersebut berdistribusi normal.

\section{UJI MULTIKOLONIERITAS}

Tabel 5

Hasil Uji Koefisien Korelasi Coefficients $^{\mathrm{a}}$

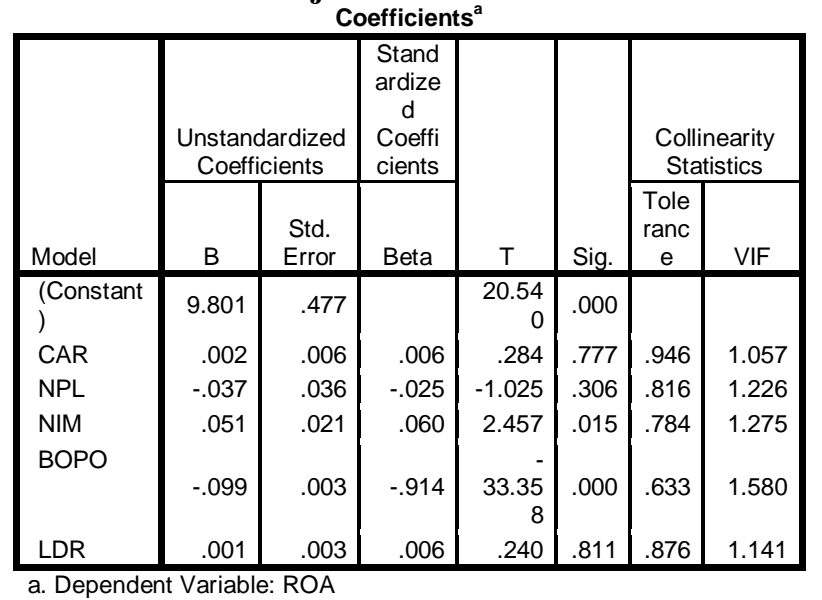

Berdasarkan Tabel 5 di atas diketahui bahwa nilai tolerance variabel CAR, NPL, NIM, BOPO, dan LDR secara berurutan adalah $0.946,0.816$, $0.784,0.633$ dan 0.876 lebih besar dari 0.10 . sementara itu nilai VIF nya secara berurutan 1.057, 1.226, 1.275, 1.580 dan 1.141 lebih kecil dari 10.00. dapat disimpulkan tidak terjadi multikolonieritas.

\section{UJI HETEROSKEDASTISITAS}

\section{Tabel 6}

Hasil Uji Koefisien Korelasi Coefficients $^{\mathrm{a}}$ 


\begin{tabular}{|c|c|c|c|c|c|}
\hline \multirow[b]{2}{*}{ Model } & \multicolumn{2}{|c|}{$\begin{array}{c}\text { Unstandardized } \\
\text { Coefficients }\end{array}$} & \multirow{2}{*}{$\begin{array}{c}\begin{array}{c}\text { Standar } \\
\text { dized } \\
\text { Coefficie } \\
\text { nts }\end{array} \\
\text { Beta } \\
\end{array}$} & \multirow[b]{2}{*}{$t$} & \multirow[b]{2}{*}{ Sig. } \\
\hline & B & $\begin{array}{l}\text { Std. } \\
\text { Error }\end{array}$ & & & \\
\hline (Constant) & .312 & .368 & & .848 & .397 \\
\hline CAR & -.003 & .005 & -.046 & -.672 & .502 \\
\hline NPL & .008 & .028 & .022 & .297 & .767 \\
\hline NIM & .054 & .016 & .256 & 3.408 & .001 \\
\hline BOPO & -.001 & .002 & -.025 & -.301 & .764 \\
\hline LDR & -.002 & .002 & -.058 & -.810 & .419 \\
\hline
\end{tabular}

signifikansi variabel CAR, NPL, BOPO dan LDR sebesar 0.502, 0.767, 0.764 dan 0.419 lebih besar dari 0.05 , artinya tidak terjadi heteroskedastisitas. Namun untuk variabel NIM memiliki niai 0.001 artinya terjai heteroskedastisitas.

\section{UJI AUTOKORELASI}

Tabel 7

Hasil Uji Auto Korelasi Model Summary ${ }^{\mathrm{b}}$

\begin{tabular}{|c|c|c|c|c|c|}
\hline \multicolumn{6}{|c|}{ Model Summary } \\
\hline $\begin{array}{l}\text { Mo } \\
\text { del }\end{array}$ & $\mathrm{R}$ & $\begin{array}{c}\mathrm{R} \\
\text { Square }\end{array}$ & \begin{tabular}{|c|} 
Adjus \\
ted R \\
Squar \\
e
\end{tabular} & $\begin{array}{l}\text { Std. Error } \\
\text { of the } \\
\text { Estimate }\end{array}$ & $\begin{array}{l}\text { Durbin- } \\
\text { Watson }\end{array}$ \\
\hline 1 & $.949^{a}$ & .901 & .898 & .56154 & 2.119 \\
\hline
\end{tabular}

Berdasarkan Tabel diatas, diketahui nilai DW 2.119. Selanjutnya niai ini dibandingkan dengan nilai tabel signifikansi 5\%, dengan jumlah sampel $\mathrm{N}=215$ dan jumlah variabel $5(\mathrm{~K}=5)$ maka diperoleh nilai dL 1.73883 dan nilai dU 1.81461. Nilai DW lebih besar dari batas atas (dU) yaitu $2.119>$ 1.81461 artinya tidak terdapat autokorelasi positif. Dan nilai (4-dU) 4 $-2.119=1.881$ lebih besar dari $\mathrm{dL}$ $(1.884>1.73883)$ artinya tidak terdapat autokorelasi negative, sehingga dapat disimpulkan bahwa sama sekali tidak terdapat autokorelasi.

\section{ANALISIS REGRESI LINEAR BERGANDA}

Tabel 9

Hasil Analisis Regresi Linear Berganda Coefficients $^{a}$

\begin{tabular}{|c|c|c|c|c|c|}
\hline \multirow[b]{2}{*}{ Model } & \multicolumn{2}{|c|}{$\begin{array}{c}\text { Unstandardized } \\
\text { Coefficients }\end{array}$} & \multirow{2}{*}{$\begin{array}{c}\begin{array}{c}\text { Standardi } \\
\text { zed } \\
\text { Coefficie } \\
\text { nts }\end{array} \\
\text { Beta }\end{array}$} & \multirow[b]{2}{*}{$\mathrm{T}$} & \multirow[b]{2}{*}{ Sig. } \\
\hline & B & $\begin{array}{l}\text { Std. } \\
\text { Error }\end{array}$ & & & \\
\hline $\begin{array}{l}1 \text { (Const } \\
\text { ant) }\end{array}$ & 9.801 & .477 & & 20.540 & .000 \\
\hline CAR & .002 & .006 & .006 & .284 & .777 \\
\hline NPL & -.037 & .036 & -.025 & -1.025 & .306 \\
\hline NIM & .051 & .021 & .060 & 2.457 & .015 \\
\hline BOPO & -.099 & .003 & -.914 & -33.358 & .000 \\
\hline LDR & .001 & .003 & .006 & .240 & .811 \\
\hline
\end{tabular}

a. Dependent Variable: ROA

Berdasarkan pada tabel di atas persamaan regresinya adalah sebagai berikut :

$\mathrm{Y}=9.801+\mathbf{0 . 0 0 2} X_{1}+(-0.037) X_{2}+$ $0.051 X_{3}+\left(\mathbf{- 0 . 0 9 9 )} X_{4}+\mathbf{+ 0 . 0 0 1} X_{5}\right.$

Persamaan regresi di atas dapat dijelaskan sebagai berikut :

- Konstanta sebesar 9.801, artinya jika CAR, NPL, NIM, BOPO dan LDR nilainya adalah 0 , maka ROA nilainya adalah 9.801 .

- Koefisien regresi variabel CAR sebesar 0.002, artinya jika variabel independen lainnya tetap dan CAR mengalami kenaikan 1\% maka ROA akan mengalami kenaikan sebesar 0.002 . koefisien bernilai positif artinya terjadi hubungan positif antara CAR dengan ROA, semakin naik CAR maka naik pula ROA.

- Koefisien regresi variabel NPL sebesar -0.037, artinya jika variabel independen lainnya tetap dan NPL 
mengalami kenaikan 1\% maka ROA akan mengalami penurunan sebesar 0.037. koefisien bernilai negatif artinya terjadi hubungan negatif antara NPL dengan ROA, semakin naik CAR maka makin turun nilai ROA.

- Koefisien regresi variabel NIM sebesar 0.051, artinya jika variabel independen lainnya tetap dan NIM mengalami kenaikan $1 \%$ maka ROA akan mengalami kenaikan sebesar 0.051 . koefisien bernilai positif artinya terjadi hubungan positif antara NIM dengan ROA, semakin naik NIM maka naik pula ROA.

- Koefisien regresi variabel BOPO sebesar -0.099, artinya jika variabel independen lainnya tetap dan BOPO mengalami kenaikan $1 \%$ maka ROA akan mengalami penurunan sebesar 0.099. Koefisien bernilai negatif artinya terjadi hubungan negatif antara BOPO dengan ROA, semakin naik BOPO maka makin turun nilai ROA.

- Koefisien regresi variabel LDR sebesar 0.001, artinya jika variabel independen lainnya tetap dan LDR mengalami kenaikan $1 \%$ maka ROA akan mengalami kenaikan sebesar 0.001 . koefisien bernilai positif artinya terjadi hubungan positif antara LDR dengan ROA, semakin naik LDR maka naik pula ROA.

ANALISIS KORELASI GANDA (R) Tabel 9

Hasil Analisis Korelasi Ganda Model Summary ${ }^{\mathrm{D}}$

\begin{tabular}{|l|c|c|c|c|}
\hline & & & $\begin{array}{c}\text { Adju } \\
\text { sted } \\
\mathrm{R}\end{array}$ & $\begin{array}{c}\text { Std. } \\
\text { Error } \\
\text { of the } \\
\text { Model }\end{array}$ \\
\hline 1 & $\mathrm{R}$ & $\begin{array}{c}\text { Squa } \\
\text { re }\end{array}$ & $\begin{array}{c}\text { Squa } \\
\text { Estima } \\
\text { te }\end{array}$ \\
\hline
\end{tabular}

a. Predictors: (Constant), LDR, NPL,

CAR, NIM, BOPO

b. Dependent Variable: ROA
Berdasarkan tabel di atas diperoleh angka $\mathrm{R}$ sebesar 0.949. hal ini menunjukan bahwa terjadi hubungan yang sangat kuat antara CAR, NPL, NIM, BOPO dan LDR terhadap ROA.

\section{ANALISIS DETERMINASI $\left(R^{2}\right)$}

Analisis determinasi dalam regresi linear berganda digunakan untuk mengetahui presentase sumbangan pengaruh variabel independen (CAR, NPL, NIM, BOPO dan LDR) secara serentak atau simultan terhadap variabel dependen (ROA). Pada penelitian ini hasil determinasi $\left(R^{2}\right)$ dapat pada Tabel 9 yaitu pada nilai R Square sebesar 0.901. Hal ini menunjukan bahwa presentase sumbangan pengaruh variabel independen terhadap variabel dependen sebesar $90.10 \%$. Atau variabel independen yang digunakan dalam model (CAR, NPL, NIM, BOPO, dan LDR) mampu menjelaskan 90.10 variasi variabel dependen (ROA). Sedangkan sisanya sebesar $9.90 \%$ dipengaruhi atau dijelaskan oleh variabel lain yang tidak dimasukan dalam model penelitian ini.

\section{UJI SIGNIFIKAN PARAMETER INDIVIDUAL (UJI t)}

Tabel 10

Hasil Uji Signifikansi Parameter Individual Coefficients $^{a}$

\begin{tabular}{|c|c|c|c|c|c|}
\hline \multirow[b]{2}{*}{ Model } & \multicolumn{2}{|c|}{$\begin{array}{c}\text { Unstandardiz } \\
\text { ed } \\
\text { Coefficients }\end{array}$} & \multirow{2}{*}{ 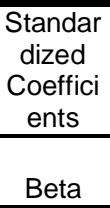 } & \multirow[b]{2}{*}{$\mathrm{T}$} & \multirow[b]{2}{*}{ Sig. } \\
\hline & B & $\begin{array}{l}\text { Std. } \\
\text { Error }\end{array}$ & & & \\
\hline $\begin{array}{l}1 \text { (Const } \\
\text { ant) }\end{array}$ & 9.801 & .477 & & 20.540 & .000 \\
\hline CAR & .002 & .006 & .006 & .284 & .777 \\
\hline NPL & -.037 & .036 & -.025 & -1.025 & .306 \\
\hline NIM & .051 & .021 & .060 & 2.457 & .015 \\
\hline BOPO & -.099 & .003 & -.914 & -33.358 & .000 \\
\hline LDR & .001 & .003 & .006 & .240 & .811 \\
\hline
\end{tabular}


1) Hipotesis 1

Hipotesis pertama digunakan untuk menguji kebenaran bahwa Capital Adequacy Ratio (CAR) berpengaruh positif dan signifikan terhadap ROA bank umum yang terdaftar di BEI pada periode 20112015.

H0: CAR tidak berpengaruh positif terhadap ROA bank umum yang terdaftar di BEI pada periode 2011-2015.

Ha: CAR berpengaruh positif terhadap ROA bank umum yang terdaftar di BEI pada periode 2011-2015.

Dari perhitungan analisis data panel untuk variabel CAR, diperoleh nilai t hitung sebesar 0.284, dan t tabel df (n-k-1) adalah 1.971. Dan nilai signifikansi sebesar 0.777 lebih besar dari alfa yaitu 0.05 , artinya memiliki signifikan, namun CAR tidak berpengaruh jadi signifikan ini tidak memiliki arti. Maka dapat disimpulkan bahwa $\mathrm{H} 0$ diterima. Artinya CAR tidak berpengaruh positif terhadap ROA bank umum yang terdaftar di BEI pada periode 2011-2015.

2) Hipotesis 2

Hipotesis ketiga digunakan untuk menguji kebenaran bahwa Non performing loan (NPL) berpengaruh negatif dan signifikan terhadap ROA bank umum yang terdaftar di BEI pada periode 20112015.

H0: NPL tidak berpengaruh negatif terhadap ROA bank umum yang terdaftar di BEI pada periode 2011-2015.

Ha: NPL berpengaruh negatif terhadap ROA bank umum yang terdaftar di BEI pada periode 20011-2015.

Dari perhitungan analisis data panel untuk variabel NPL, diperoleh nilai $\mathrm{t}$ hitung sebesar -1.025 , dan $\mathrm{t}$ tabel df (n-k-1) adalah -1.971. Dan nilai signifikansi sebesar 0.306 lebih kecil dari alfa yaitu 0.05. Maka dapat disimpulkan bahwa $\mathrm{HO}$ diterima. Artinya NPL tidak berpengaruh negatif dan signifikan terhadap ROA bank umum yang terdaftar di BEI pada periode 20112015.

3) Hipotesis 3

Hipotesis pertama digunakan untuk menguji kebenaran bahwa Net Interest Margin (NIM) berpengaruh positif dan signifikan terhadap ROA bank umum yang terdaftar di BEI pada periode 2011-2015.

H0: NIM tidak berpengaruh positif terhadap ROA bank umum yang terdaftar di BEI pada periode 2011-2015.

Ha: NIM berpengaruh positif terhadap ROA bank umum yang terdaftar di BEI pada periode 2011-2015.

Dari perhitungan analisis data panel untuk variabel NIM, diperoleh nilai t hitung sebesar 2.457, dan t tabel df (n-k-1) adalah 1.971. Dan nilai signifikansi sebesar 0.015 lebih besar dari alfa yaitu 0.05. Maka dapat disimpulkan bahwa $\mathrm{H} 0$ ditolak. Artinya NIM berpengaruh positif dan tidak signifikan terhadap ROA bank umum yang terdaftar di BEI pada periode 2011-2015.

4) Hipotesis 4

Hipotesis keempat digunakan untuk menguji kebenaran bahwa biaya operasional pendapatan operasional (BOPO) berpengaruh negatif dan signifikan terhadap ROA bank 
umum yang terdaftar di BEI pada periode 2011-2015.

H0: $\quad$ BOPO tidak berpengaruh negatif terhadap ROA bank umum yang terdaftar di BEI pada periode 2011-2015.

Ha: $\quad$ BOPO berpengaruh negatif terhadap ROA bank umum yang terdaftar di BEI pada periode 2011-2015.

Dari perhitungan analisis data panel untuk variabel BOPO, diperoleh nilai t hitung sebesar -33.358 , dan $\mathrm{t}$ tabel df (n-k-1) adalah -1.971. Dan nilai signifikansi sebesar 0.000 lebih kecil dari alfa yaitu 0.05. Maka dapat disimpulkan bahwa $\mathrm{HO}$ ditolak. Artinya

BOPO berpengaruh negatif dan signifikan terhadap ROA bank umum yang terdaftar di BEI pada periode 20112015.

5) Hipotesis 5

Hipotesis kelima digunakan untuk menguji kebenaran bahwa Loan to Deposit Ratio (LDR) berpengaruh positif dan signifikan terhadap ROA bank umum yang terdaftar di BEI pada periode 2011-2015.

H0: LDR tidak berpengaruh positif terhadap ROA bank umum yang terdaftar di BEI pada periode 2011-2015.

Ha: LDR berpengaruh positif terhadap ROA bank umum yang terdaftar di BEI pada periode 201- 2015.

Dari perhitungan analisis data panel untuk variabel LDR, diperoleh nilai t hitung sebesar 0.240, dan t tabel df (n-k-1) adalah 1.971. Dan nilai signifikansi sebesar 0.811 lebih kecil dari alfa yaitu 0.05. Maka dapat disimpulkan bahwa H0 diterima. Artinya LDR tidak berpengaruh positif dan signifikan terhadap ROA bank umum yang terdaftar di BEI pada periode 20112015 .

\section{UJI SIGNIFIKANSI SIMULTAN (UJI F)}

Tabel 11

Hasil Uji F

ANOVA $^{\mathrm{a}}$

\begin{tabular}{|l|r|r|r|r|r|}
\hline Model & $\begin{array}{r}\text { Sum of } \\
\text { Squares }\end{array}$ & \multicolumn{1}{c|}{ df } & $\begin{array}{r}\text { Mean } \\
\text { Square }\end{array}$ & F & Sig. \\
\hline $\begin{array}{l}\text { 1 Regre } \\
\text { ssion } \\
\text { Residu } \\
\text { al } \\
\text { Total }\end{array}$ & 598.448 & 5 & 119.690 & 379.567 & $\begin{array}{r}.000 \\
\mathrm{~b}\end{array}$ \\
\hline
\end{tabular}

a. Dependent Variable: ROA

b. Predictors: (Constant), LDR, NPL, CAR, NIM, BOPO

Dari Tabel di atas, nilai statistik F dapat dilihat dari nilai probabilitas $\mathrm{F}$ hitung sebesar 379.567. Nilai $F$ tabel dengan $\mathrm{dF}$ (jumlah variabel-1) 6-1 = 5, dan dF 2 (n-k-1) 215-5-1 = 209 maka diperoleh nilai $\mathrm{F}$ tabel sebesar 2.257. Nilai $\mathrm{F}$ hitung lebih besar dari $\mathrm{F}$ tabel maka H0 ditolak dan $\mathrm{Ha}$ diterima. Dengan nilai signifikansi yang lebih kecil dari alpha 0.05, maka pengaruh variabel secara simultan dikatakan signifikan. Sehingga dapat disimpulkan bahwa CAR, NPL, NIM, BOPO dan LDR secara bersama-sama (simultan) berpengaruh secara signifikan terhadap ROA bank umum yang terdaftar di BEI pada periode 2011-2015.

\section{PEMBAHASAN}

Hasil pengujian pengaruh CAR terhadap ROA tidak sesuai dengan teori dan kerangka berfikir yang 
dikembangkan. Dalam hal ini terjadi karena terdapat beberapa bank yang memiliki ketidak searahan antara CAR dan ROA. Dimana ketika CAR tinggi seharusnya nilai ROA juga ikut tinggi, namun hal tersebut berbeda dalam penelitian kali ini. Dimana CAR angkanya tinggi, namun ROA malah memiliki nilai rendah. Sebagai contoh Bank Capital Indonesia pada tahun 2011, nilai CARnya cenderung tinggi, yaitu $21.58 \%$, namun tidak sesuai dengan nilai ROA yang rendah sebesar $0.84 \%$. selain itu juga Bank Jtrust Indonesia,memiliki nilai CAR yang cukup tinggi pada tahun 2013 sebesar $14.03 \%$, sangat berbanding terbalik dengan nilai ROA yang dibawah ratarata sebesar $-7.58 \%$.

Hasil ini tidak sesuai dengan pengujian hipotesis, dimana $\mathrm{H} 0$ lah yang diterima. Artinya bahwa NPL tidak berpengaruh negatif terhadap ROA. Bank mempunyai peran penting dalam perekonomian, baik sebagai lembaga intermediasi maupun lalu lintas pembayaran. Berbagai fasilitas dan layanan pun bermunculan sebagai respon dari kebutuhan masyarakat. Salah satu fasilitas yang diberikan kepada nasabah adalah loanable funds, dimana loanable funds terbesar diberikan dalam bentuk fasilitas kredit. Pemberian kredit inilah yang kemudian berdampak pada timbulnya risiko kredit macet atau NPL.

NIM sudah sesuai dengan teori yang dikembangkan dalam kerangka berfikir. Hal ini juga sejalan dengan penelitian yang dilakukan oleh Ayuningrum (2011) dimana NIM berpengaruh positif dan signifikan terhadap ROA. Rasio NIM merupakan rasio pendapatan bunga bersih dibagi dengan jumlah kredit yang diberikan. Menurut Rusdiana (2012) rasio ini digunakan untuk mengukur kemampuan manajemen bank dalam mengelola aktiva produktifnya untuk menghasilkan pendapatan bunga bersih. Meningkatnya pendapatan bunga bersih, tentu saja akan memberikan komtribusi yang positif terhadap laba bank yang ditunjukan dengan tingginya rasio ROA.

BOPO sudah sesuai dengan teori yang dikembangkan dalam kerangka berfikir. Hal ini juga sejalan dengan penelitian yang dilakukan oleh Ayuningrum (2011) dimana BOPO berpengaruh negatif dan signifikan terhadap ROA. Sesuai dengan Surat Edaran Bank Indonesia No.15/7/DPNP tanggal 8 Maret 2013, besaran nilai BOPO tergantung dari kelompok usahanya. Bank Umum Kelompok Usaha I (BUKU I) menetapkan batas maksimal sebesar 85\%. Bank Umum Kelompok Usaha II (BUKU II) menetapkan batas ideal BOPO di kisaran 78\%-80\%. BUKU III di kisaran $70 \%-75 \%$ dan BUKU IV di kisaran $60 \%-65 \%$.

Hasil pengujian hipotesis menyimpulkan bahwa LDR tidak berpengaruh positif terhadap ROA bank umum yang terdaftar di Bursa Efek Indonesia periode 2011-2015 dengan koefisien LDR sebesar 0.001. Hasil pengujian pengaruh LDR terhadap ROA tidak sesuai dengan teori dan kerangka berpikir yang dikembangkan.

Hasil uji F pada Tabel 4.15 di atas menunjukkan nilai $\mathrm{F}$ statistik sebesar 600.103 dengan signifikansi sebesar 0.000. Nilai signifikansi F < 0.05 menunjukkan bahwa variabel CAR, NPL, NIM, BOPO dan LDR secara simultan berpengaruh signifikan terhadap ROA bank umum yang terdaftar di BEI pada periode 20112015. Berbeda halnya dengan uji 
parsial, pada uji secara simultan atau bersama-sama ini menunjukkan terdapat pengaruh variabel CAR, NPL, NIM, BOPO dan LDR terhadap ROA.

\section{KESIMPULAN}

1. CAR tidak berpengaruh terhadap ROA

2. NPL tidak berpengaruh terhadap ROA

3. NIM berpengaruh positif dan tidak signifikan terhadap ROA

4. BOPO berpengaruh negatif dan signifikan terhadap ROA

5. LDR tidak berpengaruh terhadap ROA

6. Secara bersama-sama CAR, NPL, NIM, BOPO dan LDR berpengaruh terhadap ROA.

\section{SARAN}

1. Bagi Perbankan

Nilai rata-rata ROA bank sebesar 1.5956 persen selama tahun 2011-2015. Dari tahun 2011 sampai dengan 2015 cenderung fluktuasi, namun mengalami penurunan. Pada tahun 2011-2013 secara berurutan nili ROA 1.81, 2.04 dan 1.78 persen sudah sesuai dengan ketentuan minimal yaitu ROA bank minimal 1.5 persen. Untuk tahun 2014 dan 2015 rata-rata ROA bank dibawah standar minimal yang ditetapkan yaitu sebesar 1.33 dan 1.01 persen. Oleh karena itu bank harus berupaya meningkatkan efisiensi dalam setiao operasi nya. Diantaranya bank perlu melakukan upaya seperti ekspansi kredit maupun penekanan biaya operasional untuk meningkatkan nilai ROA.

2. Bagi Peneliti Selanjutnya
Penelitian selanjutnya bisa menggunakan rasio keuangan yang lebih variatif karena masih banyak rasio keuangan yang bisa digunakan diluar dari penelitian ini.

\section{DAFTAR PUSTAKA}

Al-Khatib, Hazeem B dan Al-Horani, Alaa. 2012. Predicting Financial Distress of Public Companie Listed in Amman Stock Exchange. European Sciencitific Jurnal. Vol.8 No.15 2012.

Angel, Mendoza. 2014. Pengaruh LDR, NIM dan NPL terhadap Abnormal Return Saham Perbankan di Indonesia. Journal 236-251

Arief, Ahmed N. Anees. 2012. "Liquidity Risk and Performance of Banking System", Journal of Financial Regulation and Compliance. Vol. 20 Iss: 2, pp.182-195

Arikunto, S. (2010). Prosedur Penelitian Suatu pendekatan praktik. Jakarta: PT Rineka Cipta 2006. Prosedur Penelitian Suatu Pendekatan Praktek. Jakarta : PT. Rineka Cipta.

Ayuningrum, A.P. 2011. Analisis Pengaruh CAR, NPL, BOPO, NIM dan LDR Terhadap ROA (Studi Kasus pada Bank Umum Go Pubik yang Listed di Bursa Efek Indonesia Tahun 20052009). Skripsi : Universitas Diponegoro Semarag. 
Bank Indonesia (2016). Laporan Keuangan Bulanan Bank. Tersedia http//www.bi.go.id

\section{Bank Indonesia (1997). Surat Keputusan Direksi Bank Indonesia No. 30/1 1/Kep/Dir tanggal 27 Febuari 1998. Jakarta : Bank Indonesia}

Bank Indonesia (1997). Surat Keputusan Direksi Bank Indonesia No. 30/267/Kep/Dir tanggal 30 April 1997. Jakarta : Bank Indonesia

Bank Indonesia (1997). Lampiran Surat Edaran (SE) Bank Indonesia No. 6/23/DPNP. Jakarta : Bank Indonesia

Bank Indonesia (1998). Undangundang Perbankan No. 10. Jakarta : Bank Indonesia

Creswell, W. John (2008). Educational Research, Planing, Conducting, and Evaluating Qualitative \& Quantitative Approaches. London: Sage Publication

$\begin{array}{ccc}\text {....... (2010). } & \text { Research Design } \\ \text { Pendekatan } & \text { Kualitatif, } \\ \text { Kuantitatif, } & \text { dan } \text { Mixed. } \\ \text { Yogyakarta }: & \text { Pusaka Pelajar }\end{array}$

Darmawati, Deni. 2006. Pengaruh Karakteristik Perusahaan dan Faktor Regulasi Terhadap Kualitas Implementasi Good Corporate Governance. Simposium Nasional Akuntansi IX.23-26 Agustus 2006. Padang.

Dilley, Deborah K. 2010. Essentials of Banking. Canada: John Wiley \& Sons, Inc.
Flamini, Valentina dkk. (2009). The Determinants of Commercial Bank Profitability in Sub-Saharan Afrika. Jurnal: Afrika

Ghozali, Imam. 2005. Aplikasi Analisis Multivariative dengan Program SPSS. Universitas Diponegoro Semarang.

Kasmir (2007). Manajemen Perbankan.Jakarta : PT Raja Grafindo Persada
....... (2007). Dasar dasar Perbankan.Jakarta : PT Raja Grafindo Persada . (2008). Bank dan Lembaga Keuangan Lainnya. Jakarta : PT Rajagrafindo Persada ........ (2011). Analisis Laporan Keuangan: Jakarta : PT RajaGrafindo Persada.

Mahardian, Pandu. 2008. Analisis Pegaruh Rasio CAR, BOPO, NPL, NIM dan LDR terhadap Kinerja Keuangan Perbankan (Studi Kasus Perusahaan Perbankan yang Tercatat di BEJ Periode Juni 2002-2007). Tesis : Universitas Diponegoro, Semarang

Mashuri (2008). Penelitian Verifikatif. Yogyakarta: Andi

Mudrajad Kuncoro, Suhardjono. (2002). Manajemen Perbankan Teori dan Aplikasi. Yogyakarta: BPFE

Munawir, S. (2008). Analisis Informasi Keuangan. Yogyakarta : Liberty

Narimawati, U (2007). Metodologi Penelitian Kualitatif dan Kuantitatif, Teori dan Aplikasi. Bandung: Agung Media 
Program Studi Magister Manajemen

Fakultas Pascasarjana

Universitas Komputer Indonesia 